\begin{tabular}{|l|l|l||}
\hline \multicolumn{2}{|c|}{ PublisherInfo } \\
\hline \hline PublisherName & $:$ & BioMed Central \\
\hline \hline PublisherLocation & $:$ & London \\
\hline \hline PublisherImprintName & $:$ & BioMed Central \\
\hline \hline
\end{tabular}

\title{
Automated analysis of tissue microarrays
}

\begin{tabular}{||l|l|l||}
\hline \multicolumn{2}{|c|}{ ArticleInfo } \\
\hline \hline ArticleID & $:$ & 4618 \\
\hline \hline ArticleDOI & $:$ & $10.1186 /$ gb-spotlight-20021023-01 \\
\hline \hline ArticleCitationID & $:$ & spotlight-20021023-01 \\
\hline \hline ArticleSequenceNumber & $:$ & 284 \\
\hline \hline ArticleCategory & $:$ & Research news \\
\hline ArticleFirstPage & $:$ & 1 \\
\hline \hline ArticleLastPage & $:$ & 2 \\
\hline \hline & & RegistrationDate : 2002-10-23 \\
ArticleHistory & $:$ & OnlineDate $\quad$ 2002-10-23 \\
\hline \hline ArticleCopyright & $:$ & BioMed Central Ltd2002 \\
\hline \hline ArticleGrants & $:$ & \\
\hline \hline ArticleContext & $:$ & 130593311 \\
\hline \hline
\end{tabular}




\section{Jonathan B Weitzman}

Email: jonathanweitzman@hotmail.com

Analysis of histological sections of disease tissues has traditionally relied on pathologist-based scoring. In an Advanced Online Publication in Nature Medicine Camp et al. describe techniques to automate the analysis of tissue microarrays that contain hundreds of tumour tissue sections arrayed on glass slides (Nature Medicine, 21 October 2002;doi:10.1038/nm791). Their approach, nicknamed AQUA (Automated Quantitative Analysis), involves a set of algorithms that can distinguish subcellular compartments and quantitatively assess protein localisation. Validation experiments demonstrated that the AQUA methodology is at least as good as conventional pathologist-based evaluation. Camp et al. used this technique successfully to assess estrogen receptor immunohistochemistry of breast carcinoma samples and nuclear beta-catenin expression in colon cancer.

\section{References}

1. Nature Medicine, [http://www.nature.com/nm]

2. Tissue microarrays for high-throughput molecular profiling of tumor specimens,

3. Yale Cancer Center Tissue Microarray Facility, [http://www.yalepath.org/dept/research/YCCTMA/ tisarray.htm] 